\title{
Development of Three-Wavelength Polarization-Raman Lidar and APplication to SHipborne Measurements Zhangjun Wang ${ }^{1 *}$, Libin Du${ }^{1}$, Xianxin $\mathrm{Li}^{1}$, Bin $\mathrm{Zhou}^{2}$, Xiangqian Meng ${ }^{1}$, Chao Chen ${ }^{1}$, Qiaojun Liu ${ }^{1}$, Xingtao Liu ${ }^{1}$ \\ ${ }^{1}$ Shandong Academy of Sciences Institute of Oceanographic Instrumentation, Qingdao, 266001, China, *Email: zhangjun.wang@hotmail.com \\ ${ }_{2}^{2}$ Marine Engineering Prospecting Institute of North China Sea, SOA, Qingdao, 266033, China
}

\begin{abstract}
A Three-Wavelength Polarization-Raman Lidar (TWPRL) system for aerosol and clouds was developed. This lidar system provides $\alpha$ at 532 and $355 \mathrm{~nm}, \beta$ at 355, 532 and $1064 \mathrm{~nm}$, and $\sigma$ at $532 \mathrm{~nm}$ as well as water vapor content using Raman lidar techniques. The temporal and vertical variation of aerosols and clouds could be determined. We conducted shipborne TWPRL measurements over Yellow Sea of China from August to September in 2014. The derived aerosol optical properties indicate that the developed lidar system worked very well. 24-hour continuous measurements with the shipborne TWPRL during the cruise are presented.
\end{abstract}

\section{INTRODUCTION}

Atmospheric aerosols have many effects on global warming and cooling, through altering the radiative properties of the atmosphere ${ }^{[1]}$. Knowledge of the vertical structure of cloud and aerosol scattering properties or layers from varying climate regimes is fundamental to understand their role in the atmospheric processes as well as on human health and environment.

Lidar measurements of atmospheric aerosol profiles have become important for atmospheric researchers during last decades. Since 2001, The National Institute for Environmental Studies (NIES) has been constructing ground-based lidar networks with automated dual wavelength/polarization Mie-Lidar systems to observe air quality in the Asian region ${ }^{[2]}$. From June 2006, CALIOP (Cloud-Aerosol Lidar with Orthogonal Polarization) has been measuring global aerosol and cloud vertical distributions continuously with very high spatial resolution ${ }^{[3]}$. Aerosol optical and microphysical properties by ground-based sunphotometer measurements and aerosol vertical profiles by lidar measurements, performed within AERONET ${ }^{[4]}$ and MPLNET ${ }^{[5]}$, are used to analyze aerosols effects on radiative budget and atmospheric heating rate profiles. Within the European Aerosol Lidar Research Network (EARLINET) ${ }^{[6]}$, now part of the Aerosols, Clouds, and Trace gases Research InfraStructure Network (ACTRIS), more than 30 lidar systems were used to monitor the aerosol vertical distribution over Europe.

In addition, ships provide a mobile platform in oceans allowing the cover of large geographical regions. Single-wavelength lidars were used during field campaign like INDEOX ${ }^{[7]}, \mathrm{ACE}^{[8]}$, ACE-Asia ${ }^{[9]}$. Dual-wavelength Mie/polarization lidar measured the aerosol in the northern west Pacific region ${ }^{[10]}$. Kanitz et al. ${ }^{[11]}$ deployed a multiwavelength Raman lidar (Polly ${ }^{\mathrm{XT}}$ ) with a polarization-sensitive receiver channel on $\mathrm{RV}$ Polarsten. The cruise went from Bremerhaven, Germany to Punta Aernas, Chile from 16 October 2009 to 25 November 2009.

A Three-Wavelength Polarization-Raman Lidar (TWPRL) was designed and developed in Shandong Academy of Sciences Institute of Oceanographic Instrumentation (SDIOI) for aerosol and clouds measurement. The lidar system was tested and performed aboard the research vessel Xiangyanghong No. 8 over the Yellow Sea and Jiaozhou Bay of China from 29 Aug. to 2 Sept. 2014. The data presented here give information on the vertical distribution and optical properties of the Jiaozhou Bay and Yellow Sea of China during the lidar campaign. 24-hour continuous measurements with the shipborne TWPRL during the cruise are also presented.

\section{LIDAR SYSTEM}

The configuration and specifications of the 
TWPRL system are presented at Figure 1 and Table 1. This is a typical lidar instrument containing Nd:YAG laser as a transmitter, Schmidt-Cassegrain telescope to collect scattered laser radiation, dichroic beam splitter to split beam of light from the telescope and set of photodetectors connected to the PC computer.

The lidar is conceived to perform vertical measurements. The transmitter emits laser pulses at 355,532 , and $1064 \mathrm{~nm}$ with a repetition rate of $20 \mathrm{~Hz}$. All three laser beams are aligned on two optical axes: one is the $355 \mathrm{~nm}$ channel; another one is the 532 and $1064 \mathrm{~nm}$ channel. The outgoing laser beams are expanded by a $5 \mathrm{X}$ beam expander to reduce the divergence angle, and then directed into the sky through a set of mirrors.

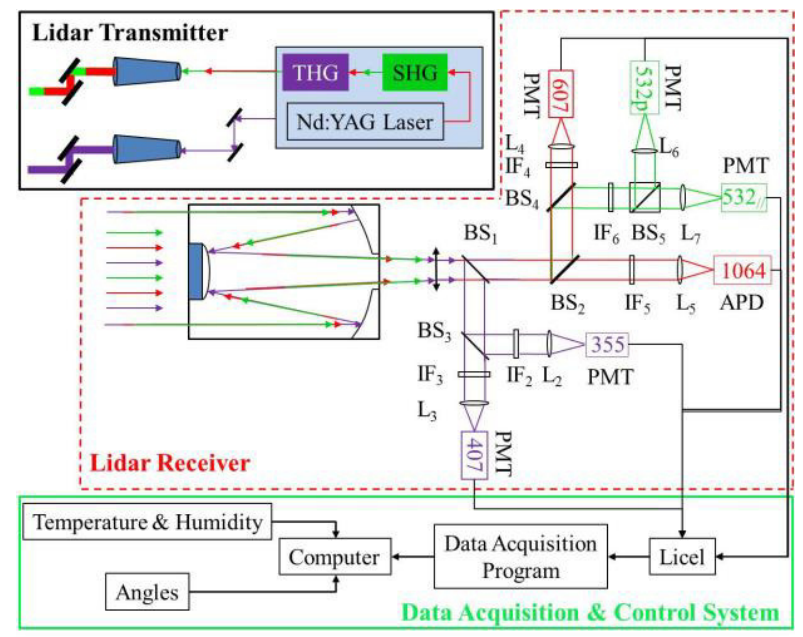

Figure 1. The three-wavelength Polarization-Raman lidar system configuration.

The laser beam is coupled from side into the fieldof-view (FOV) of the receiver telescope. Behind the pinhole, a collimating lens (L) collimates and transmits the light to six channels. The beam is separated according to wavelength with beam splitters and transmitted to photomultipliers. The Dichroic Beam Splitters (DBSs) were selected to reflect light with shorter wavelengths and transmit light with longer wavelengths because it is easier to produce DBS with higher transmission values at the longer wavelengths than at the shorter wavelengths. The signals are acquired using Licel transient recorder with 6 modules. Narrow band interference filter is used to suppress the sky background radiation in order to increase the signal-to-noise ratio (SNR) in each channel.
Table 1. Specifications of the TWPRL system

\begin{tabular}{|c|c|}
\hline Size & $\begin{array}{l}1.7 \mathrm{~m}(\mathrm{H}) * 1.25 \mathrm{~m}(\mathrm{~W}) * 0.7 \\
\mathrm{~m}(\mathrm{D})(\text { Container: } 2 \mathrm{~m} * 2 \\
\mathrm{m} * 2 \mathrm{~m})\end{array}$ \\
\hline Weight & $300 \mathrm{~kg}$ (without container) \\
\hline \multicolumn{2}{|l|}{ Transmitter } \\
\hline Laser type & $\begin{array}{ll}\text { Flash-Lamp } & \text { pumped } \\
\text { Nd:YAG laser } & \\
\end{array}$ \\
\hline Wavelength & 355,532 and $1064 \mathrm{~nm}$ \\
\hline $\begin{array}{ll}\text { Single } & \text { Pulse } \\
\text { Energy } & \end{array}$ & $\begin{array}{l}80 \mathrm{~mJ} @ 355 \mathrm{~nm}, \\
\mathrm{~mJ} @ 532 \mathrm{~nm}, \\
\mathrm{~mJ} @ 1064 \mathrm{~nm}\end{array}$ \\
\hline Repetition Rate & $20 \mathrm{~Hz}$ \\
\hline Divergence Angle & $\begin{array}{l}0.15 \text { mrad (using a } 5 x \\
\text { expander) }\end{array}$ \\
\hline \multicolumn{2}{|l|}{ Receiver } \\
\hline Telescope & $\begin{array}{l}\text { Schmidt-Cassegrain, } \mathrm{D}=30 \\
\mathrm{~cm}\end{array}$ \\
\hline Field of View & $0.3 \mathrm{mrad}$ \\
\hline Interference Filter & $\begin{array}{l}1 \mathrm{~nm}(\mathrm{FWHM}) \text { for each } \\
\text { wavelength }\end{array}$ \\
\hline \multirow[t]{2}{*}{ Detectors } & APD for $1064 \mathrm{~nm}$ \\
\hline & $\begin{array}{l}\text { PMT for } 355,532,407 \text { and } \\
607 \mathrm{~nm}\end{array}$ \\
\hline \multicolumn{2}{|c|}{ Data Acquisition and Control system } \\
\hline $\begin{array}{l}\text { Data acquisition } \\
\text { card }\end{array}$ & $\begin{array}{l}\text { Licel Transient recorder ( } 40 \\
\text { MHz, } 12 \text { bit) }\end{array}$ \\
\hline Height resolution & $3.75 \mathrm{~m}$ \\
\hline Maximum altitude & $40 \mathrm{~km}$ \\
\hline Angles of the ship & MTi-G-700 $\left(0.2^{\circ}\right)$ \\
\hline
\end{tabular}

From the elastically backscattered signals, and signals inelastically (Raman) scattered from nitrogen and water vapor molecules, we determine particle volume backscatter coefficients at 355 , 532 , and $1064 \mathrm{~nm}(3 \beta)$, and particle volume extinction coefficients at $355 \mathrm{~nm}$ and $532 \mathrm{~nm}(2 \alpha)$, depolarization ratio $(\sigma)$, and water vapor mixing ratio at $407 \mathrm{~nm}$. In order to deploy it on the Xiangyanghong No.8, the lidar system was housed in a constant temperature and constant humidity container.

\section{RESULTS}

Figure 2 shows the cruise line of the Xiangyanghong No.8 during the campaign, which started on 29 Aug. and ended on 2 Sept. 2014. 
The cruises went from the Black Point $\left(120.2967^{\circ}\right.$ $\left.\mathrm{E}, 36.0510^{\circ} \mathrm{N}\right)$ at $8: 00$ to Blue Point $\left(120.5652^{\circ} \mathrm{E}\right.$, $35.9601^{\circ} \mathrm{N}$ ) at $10: 00$ on 30 August 2014. Then we did measurement more than 24 hours in Blue Point. The second cruise started in the Blue Point in the Yellow Sea of China at 18:00 on 31 August 2014 towards the Purple Point in the Jiaozhou Bay and a further day-night observation was made.

The signals are recorded up to $50 \mathrm{~km}$ with $3.75 \mathrm{~m}$ resolutions and every 1000 pulse. In the analysis, the signals are averaged over 2.5 minute in time and $30 \mathrm{~m}$ in range. We conducted 24-hour continuous measurements and fixed position observations with the developed TWPRL during the cruise.

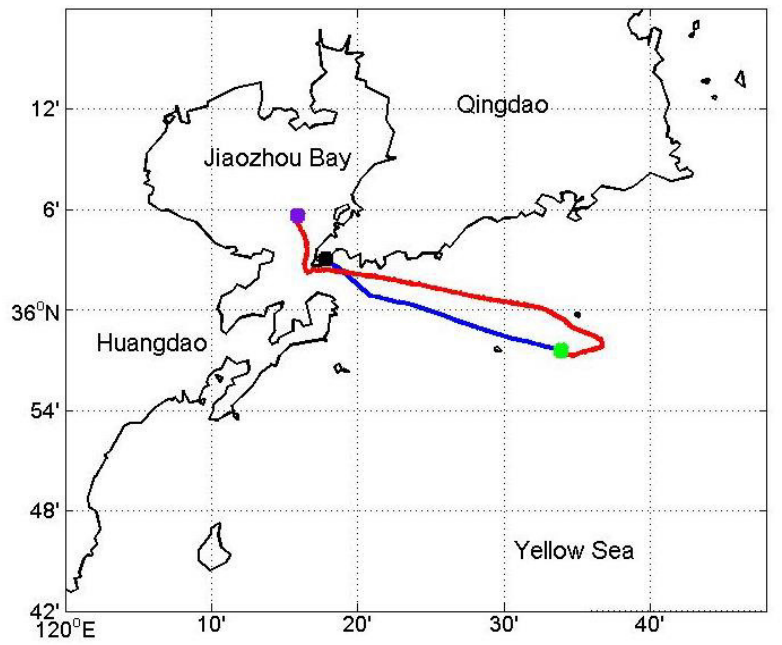

Figure 2. The cruise of the Xiangyanghong No.8

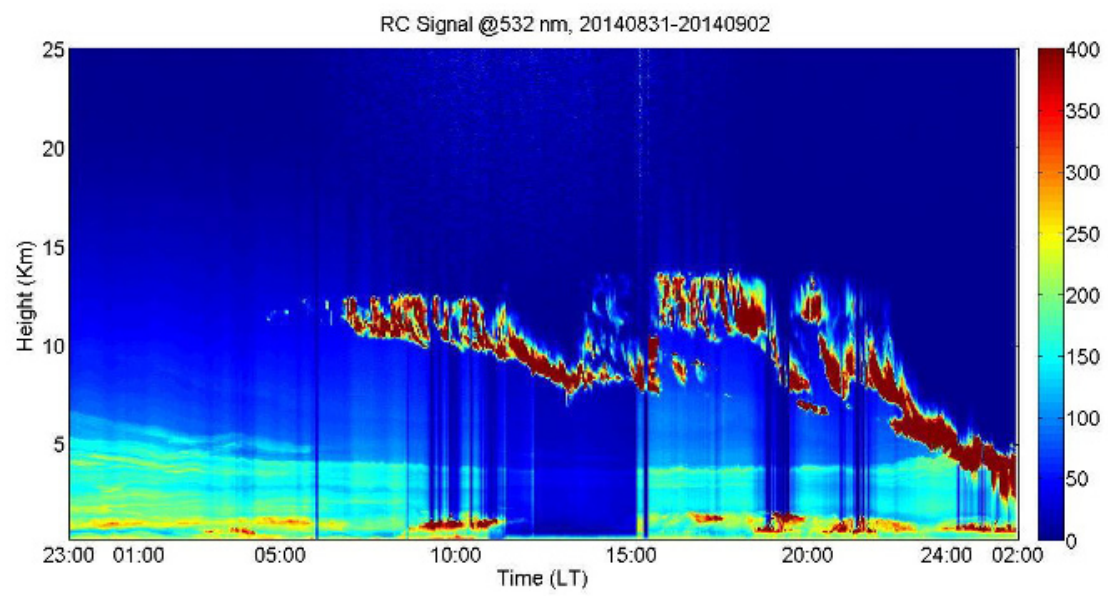

Figure 3. Time-Height display of the range-corrected signal measured in fixed position.

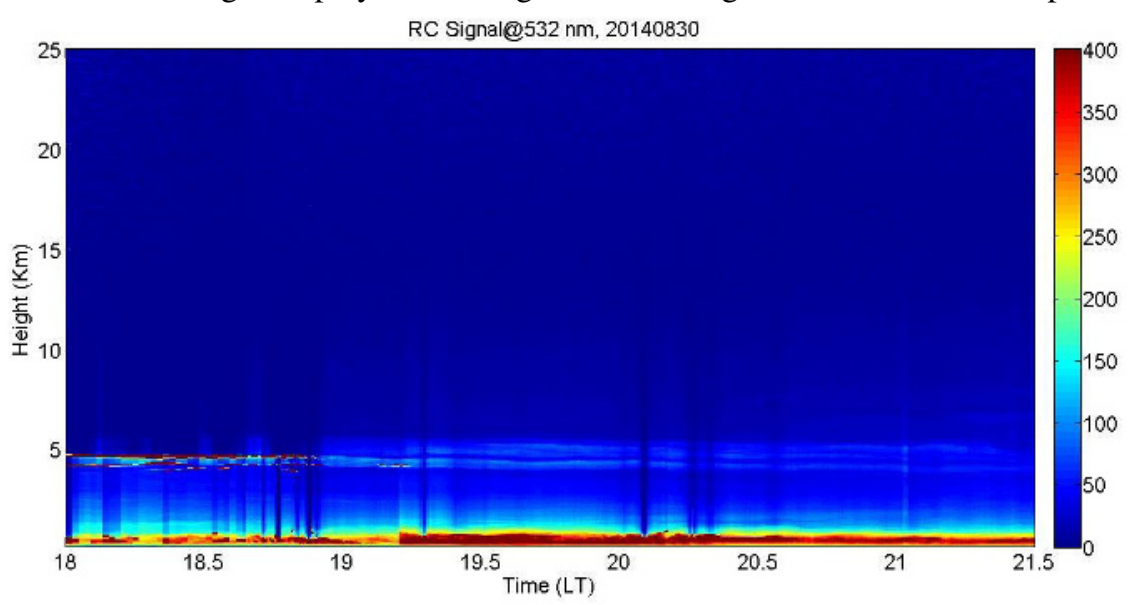

Figure 4. Time-Height display of the range-corrected signal measured along the sea route.

Two examples of the measurement results are depicted in Figure 3 and Figure 4. Figure 3 shows the 27-hour continuous measurements from 23:00 on 31 Aug. to 02:00 on 02 Sept. over the Jiaozhou
Bay $\left(120.2649^{\circ} \mathrm{E}, 36.0939^{\circ} \mathrm{N}\right)$. The height of clouds decreases from $13 \mathrm{~km}$ at 16:00 to $3.5 \mathrm{~km}$ at 02:00 on 02 Sept., then it is raining. Figure 4 presents the latitude-longitude-dependent aerosol 
vertical distribution observed at $532 \mathrm{~nm}$ along the sea route from $\left(120.5652^{\circ} \mathrm{E}, 35.9601^{\circ} \mathrm{N}\right)$ to $\left(120.2649^{\circ} \mathrm{E}, 36.0939^{\circ} \mathrm{N}\right)$.

\section{CONCLUSIONS}

A three-wavelength Polarization-Raman lidar was developed and conducted aboard the Xiangyanghong No. 8 from August to September 2014. The lidar system works very well during this campaign. The vertical distribution of marine aerosol over Yellow Sea was measured in fixed position for more than 24 hours. Furthermore, it is planning to do another two lidar campaign in May 2015 and September 2015 over the Yellow Sea of China.

\section{ACKNOWLEDGEMENT}

The study is funded by the Public science and technology research funds projects of ocean under grant No. 201205036, the International Science \& Technology Cooperation Program of China under grant No. 2011DRF20090, the Progress Program of Science and Technology of Sh andong with grant No. 2014GSF117006, and grant No. 13-1-4-183-jch supported by Qingdao Municipal Science and Technology Commission.

\section{REFERENCES}

[1]Leon J. F., Chazette P., Pelon J., Dulac F., and Randriamiarisoa H., 2002: Aerosol direct radiative impact over the INDOEX area based on passive and active remote sensing, Journal of Geophysical Research, 107 (D19), 8006.

[2]Shimizu A., Sugimoto N., Matsui I., Arao K., Uno I., Murayama T., Kagawa N., Aoki K., Uchiyama A., Yamazaki A., 2004: Continuous observations of Asian dust and other aerosols by polarization lidars in China and Japan during ACE-Asia, Journal of Geophysical Research: Atmospheres, 109 (D19), S17.

[3]Winker D. M., Hunt W. H., and McGill M. J., 2007: Initial performance assessment of CALIOP, Geophysical Research Letters, 34(19), L19803.

[4]Holben B. N., Eck T. F., Slutsker I., Tanre D., Buis J. P., Setzer A., Vermote E., Reagan J. A., Kaufman Y. J., Nakajima J., Lavenu F., Jankowiak I., and Smirnov A., 1998: AERONETA federate instrument network and data archive for aerosol characterization, Remote Sens. Environment., 6, 1-16.
[5]Welton E. J., Berkoff, T. A., et al., 2010: The NASA micropulse lidar network (MPLNET): summary of the last 10 years, current status, and future plans, 25th International Laser Radar Conference, 875-878.

[6]Matthais V., et al., 2004: Aerosol lidar intercomparison in the framework of the EARLINET project. 1, Instruments, Appl. Opt., 43(4), 961-976.

[7]Welton E. J., Voss. K. J., Quinn. P. K., Flatau. P. J., Markowicz K., Campbell. J. R., Spinhirne. J. D., Gordon H. R., Johnson J. E., 2002: Measurements of aerosol vertical profiles and optical properties during INDOEX 1999 using micropulse lidars, Journal of Geophysical Research, 107(D19), 8019.

[8]Welton E. J., Voss K. J., Gordon H. R., Maring H., Smirnov A., Holben B., Schmid B., Livingston J. M., Russell P. B., Durkee P. A., Formenti P., and Andreae M. O., 2000: Groundbased lidar measurements of aerosols during ACE-2: instrument description, results, and comparisons with other ground-based and airborne measurements, Tellus B., 52, 636-651.

[9]Schmid B., Hegg D. A., Wang J., Bates D., Redemann J., Russell P. B., Livingston J. M., Jonsson H. H., Welton E. J., Seinfeld J. H., Flagan R. C., Covert D. S., Dubovik O., and Jefferson A., 2003: Column closure studies of lower tropospheric aerosol and water vapor during ACEAsia using airborne Sun photometer and airborne in situ and ship-based lidar measurements, Journal of Geophysical Research: Atmospheres, 108(D23), 8656.

[10]Sugimoto N., Matsui I., Liu Z., Shimizu A., Asai K., Yoneyama K., and Katsumata M., 2001: Latitudinal distribution of aerosols and clouds in the western Pacific observed with a lidar on board the research vessel Mirai, Geophys. Res. Lett., 28, 4187-4190.

[11]Kanitz. T., Ansmann A., Englemann R., and Althausen D., 2013: North-south cross sections of the vertical aerosol distribution over the Atlantic Ocean from multiwavelength Raman/polarization lidar during Polarsten cruises, Journal of Geophysical Research: Atmospheres, 118, 26432655. 